\title{
경부종괴의 진단
}

부산대학교 의과대학 이비인후과학교실

$$
\text { 왕 수 건·이 진 춘 }
$$

\section{Diagnosis of Head and Neck Mass Lesions}

Soo-Geun Wang, MD and Jin-Choon Lee, MD

Department of Otolaryngology, College of Medicine, Pusan National University, Busan, Korea

\section{서 론}

경부 종괴의 진단은 내과 영역 만큼이나 다양하고 어려 운 경우가 많다. 임상에서 흔히 경부의 종괴를 접하게 되 며, 대부분 양성인 경우가 많지만 악성인 경우를 간과하 고 넘어가서는 안된다. 그러므로 전반적인 종괴에 대한 진단 방법을 숙지하고 있어야 한다. 일반적으로 경부종 괴를 진찰할 경우 고려해야 할 사항은 첫째 나이이다. 15 세 이하, 16세에서 40세, 40세 이상으로 나누어 어느 나 이에 어떤 종괴가 발생하는지 알고 있어야 한다(Table 1). 그리고 두 번째 고려해야 할 사항은 종괴의 발생 부위 이다(Table 2). 전경부에 발생하는지 측경부에 발생하 는지에 따라 종괴의 종류가 다를 수 있기 때문이다. 또 한 림프관을 따라 발생하였을 경우 그 위치에 따라 악 성종양의 원발부위와 감염의 경로 등을 예측할 수 있다. 마지막으로 고려해야 할 사항은 환자 각 개인의 특별한 과거력과 철저한 이학적 검사이다. 환자마다 특별한 소 견을 바탕으로 진단적 검사의 방법을 줄이고 가능한 원 인을 찾을 가능성을 높일 수 있다. ${ }^{1)}$

경부 종괴는 다양한 임상증상과 특징을 갖고 있으므 로 정확히 진단하여 적절히 치료할 수 있는 능력을 가 져야 한다.

교신저자 : 왕수건 , 602-739 부산광역시 서구 아미동 1 가 10 부산대학교 의과대학 이비인후과학교실 전화 : (051) 240-7331 · 전송 : (051) 246-8668 E-mail :wangsg@pusan.ac.kr

\section{경부종괴의 진단}

\section{병 력}

주의 깊은 병력의 청취는 경부종괴를 진단하는 중요한 단서를 제공한다. 환자의 나이, 종괴의 크기, 위치 및 종 괴의 지속기간 등이 가장 중요한 예측인자이다. ${ }^{2}$

연령이 어릴수록 선천성 기형을 고려해야 하고 연령 이 많을 수록 종양의 가능성이 높아진다. 그리고 경부종 괴의 위치를 정확히 확인하는 것도 진단에 도움이 된다. 특히 선천성 기형은 발생위치가 대부분 일정하기 때문 에 종양이나 감염과 감별이 가능하다. 또한 성장속도도 진단에 도움이 될 수 있는데 악성종양은 성장속도가 양 성보다 빠르고 가끔 통증도 유발한다. 그러나, 양성종양 은 시일이 지나면 크기가 줄어드는 양상을 보인다.

병력 청취에 있어 감염이나 염증의 증상(열, 통증, 압 통등)이 있었는지 확인해야 하며, 최근에 결핵, sarcoidosis, 진균감염의 병력이 있는지, 혹은 치아 문제, 두경부 의 외상 병력이 있는지 등을 알아보는 것이 중요하다. 대부분 감염이나 염증의 증상이 있었던 경우엔 양성일 가능성이 높다.

경부 종괴가 발생할 경우 가장 주의해야 할 사항은 악성 종양과의 감별이다.

그러므로 아래의 사항을 주의깊게 알아보아야 한다. 첫째, 이전에 두경부에 악성종양(피부암, 흑색종, 갑상 선암, 혹은 다른 두경부 암) 을 않은 병력이 있는지 여부 를 확인한다. 둘째, 야간 발한이 있는지 여부(림프종의 
Table 1. Cause of neck mass according to age

\begin{tabular}{|c|c|c|c|c|}
\hline & Infant & Child & Adolescent & Adult \\
\hline Neoplastic & & $\begin{array}{l}\text { Neoplastic } \\
\text { (parotid, thyroid) }\end{array}$ & $\begin{array}{l}\text { Lymphoma } \\
\text { (Hodgkin's) }\end{array}$ & $\begin{array}{l}\text { Metastatic cancer } \\
\text { lymphoma } \\
\text { (Hodgkin's/non- } \\
\text { Hodgikin's) } \\
\text { thyroid }\end{array}$ \\
\hline $\begin{array}{l}\text { Infective } \\
\text { /inflammation }\end{array}$ & $\begin{array}{l}\text { Non-specific } \\
\text { lymphadenitis }\end{array}$ & $\begin{array}{l}\text { Non-specific } \\
\text { lymphadenitis } \\
\text { cat scratch disease } \\
\text { mycobacteria mumps } \\
\text { (viral parotitis) }\end{array}$ & $\begin{array}{l}\text { Glandular fever } \\
\text { dental infection } \\
\text { cat scratch disease } \\
\text { toxoplasmosis } \\
\text { mumps (viral parotitis) }\end{array}$ & $\begin{array}{l}\text { Dental infection } \\
\text { HIV lymphadenopathy } \\
\text { toxoplasmosis } \\
\text { cat scratch disease } \\
\text { TB }\end{array}$ \\
\hline Congenital & $\begin{array}{l}\text { Cystic hygroma } \\
\text { vascular } \\
\text { malformation } \\
\text { congenital torticollis }\end{array}$ & $\begin{array}{l}\text { Dermoid cysts } \\
\text { vascular } \\
\text { malformations }\end{array}$ & $\begin{array}{l}\text { Thyroglossal cyst } \\
\text { branchial cysts }\end{array}$ & $\begin{array}{l}\text { Congenital } \\
\text { sebaceous cyst }\end{array}$ \\
\hline
\end{tabular}

Table 2. Neck masses by location

Lateral neck mass
branchial anomalies
laryngocele
pseudotumor of infancy
Midline
thyroglossal duct cyst
thymic cyst
dermoid cyst
plunging ranula
teratoma of the neck
Entire neck
hemangioma
lymphatic malformation

가능성)를 확인한다, 셋째, 과도한 흡연과 음주의 경력 (두경부의 편평상피암의 가능성)이 있는지 여부를 확인 한다. 넷째, 비출혈, 이통, 연하통, 연하장애, 혹은 애성 (상부 호흡소화기관 암의 가능성)의 여부를 확인한다. 마지막으로 방사선 조사의 과거력(갑상선 암의 가능성) 이 있는지 여부를 확인한다. 악성 림프종은 두경부에 국 한된 질환은 아니지만 호지킨씨병 (Hodgkin's disease) 의 $70 \%$, 비호지킨 림프종(non-Hodgkin's lympho$\mathrm{ma}$ ) 의 $30 \%$ 가량에서 경부 림프절을 침범하여 경부 종 괴 형태로 나타나므로 청소년층에서 경부 종괴에 대한 조사를 할 때는 이에 대한 의심도 아울러 해야 한다.

\section{이학적 검사}

경부종괴의 진단에 있어서 가장 중요한 단계는 이학 적 검사이다. 시진과 촉진이 가장 중요한 요소인데 이러 한 이학적 검사로 종괴의 위치, 주위조직과의 관계, 종 괴의 경도, 박동유무등을 알 수 있다. 종괴의 박동을 듣 는다던지 호흡에서 괴사성 종양의 특징적인 냄새를 맡 는 것도 중요하다. ${ }^{4)}$ 특히 경부의 이학적 검사에는 밝은 광원과 굴곡형 후두내시경으로 상부 호흡소화기관의 모 든 점막을 자세히 관찰하는 자세가 필요하다. ${ }^{4)}$

이학적 검사시 피부의 변화를 포함하여 종물의 외양, 특수한 냄새까지 치밀한 조사가 필요하고, 혈관 기원의 종양에서는 청진으로 잡음(bruit)을 들을 수 있으며, 촉 진 및 압박검사로 혈류의 존재를 파악할 수 있다.

경부 종괴의 촉진시 환자의 뒤쪽에서 환자의 머리를 촉진하고자 하는 쪽으로 기울이게 하여 흥쇄유돌근의 긴 장도를 낮춘 후 하부 림프절군(inferior group)부터 상 부로 세밀하게 촉지해 나간다. 이후 턱밑(submental), 하악하(submaxillary), 후경부(posterior triangle) 순 으로 촉진하고 흉골 상연(sternal notch)에서 설골(hyoid bone) 까지 촉진한다. ${ }^{5)}$

이후 구강(oral cavity), 인두(pharynx), 후두(lary$\mathrm{nx}$ ) 등을 간접 반사경(indirect mirror), 혹은 굴절 내 시경(fiberoptic tool)을 이용해 검사하고 가능한 경우 수지를 이용한 촉진도 필수적이다. ${ }^{5)}$ 


\section{영상진단}

박동성이거나 압박성이거나 맥박이나 잡음이 들리는 경부 종괴를 가지는 환자에게는 두가지의 감별해야 할 질환이 있다. 혈관성 종괴(동맥류 등)인지 종양성 종괴 (경동맥체 종양 혹은 glomus 종양인지) 인지를 감별하 는데 혈관조영술과 초음파가 필요하 듯 종괴의 특성에 따라 검사의 종류가 다르기 때문에 적절한 검사를 선택 하여야 한다. ${ }^{4)}$

\section{초음파 검사}

초음파는 낭성종물과 고형종물의 감별(Fig. 1), 혹은 고 형의 림프절, 신경성 종양, 이소성 갑상성 조직과 선청 성 새열낭종, 갑상설골낭종과 감별하는데 도움을 준다. $\mathrm{A}$ 모드와 B 모드 스캔을 이용한 고형종양과 고형및 낭 성종양의 혼합종양, 그리고 낭성종양을 감별하는데 초음 파검사의 정확성은 약 $90 \%$ 에서 $95 \%$ 정도이다. ${ }^{4)}$ 타액 선의 병변이 있을 경우에도 초음파가 유용하다.

\section{핵의학검사}

핵의학검사(radionuclide scan)는 종괴가 기능성인지,

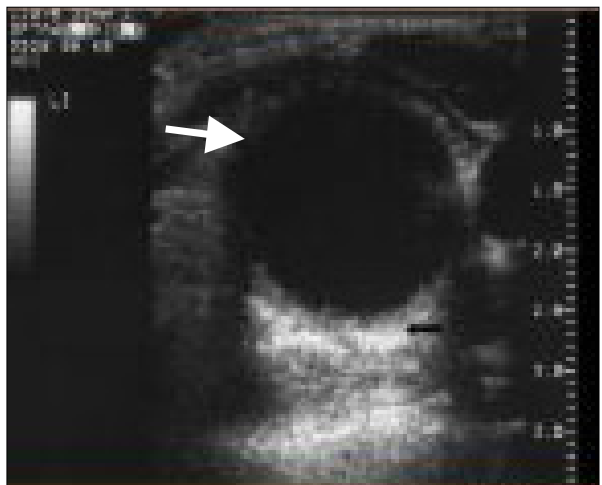

Fig. 1. Ultrasonographic imaging of thyroid cystic mass (white arrow).
비기능성인지 확인하는데 유용하다. 근래 각광받고 있는 새로운 핵의학 검사로는 양전자 방출 단층 촬영술(positron emission tomography, PET)이 있다(Fig. 2). ${ }^{4}$

$\mathrm{PET}$ 검사는 종괴가 기능성인지 여부를 아는데 유용 하고 CT나 MRI에서 나타난 림프절 전이의 치료 판정 에 널리 이용된다. 또한 방사선 조사후 재발 여부를 판 정하는데도 유용하다. ${ }^{4)}$

하지만 고가의 비용과 타액선의 활동성, 해상도의 제 한에 의한 높은 가양성율(false positive) 때문에 내시 경 혹은 초음파 유도하 조직검사 등에서 일차암을 발견 하지 못한 경우를 제외하곤 잘 시행되지 않았다. ${ }^{6}$ 하지 만, 최근에는 우리나라에서 보험수가 적용으로 인하여 암 환자의 재발판정등에 널리 이용되고 있다. 마비된 반 대쪽 성대, 육아종성 림프선병증(lymphadenopathy), 그리고 Warthin씨 종양 같은 타액선 종양이 있을 경우 엔 가양성율이 높다. ${ }^{7)}$

\section{전산화 단층촬영 $(\mathrm{CT})$ 과 자기공명영상(MRI)}

두검사 모두 경부 종괴 진단에 가장 유용한 검사이다. 고형 종괴와 낭성 종괴의 감별, 선조직내에 위치하거나 림프절 사슬내에 위치하는 종괴의 감별, 혈관성 종양의 감별에 특히 유용하다. 대부분의 경부 종괴의 진단에 세 침흡인검사와 더불어 전적으로 이용되고 있다. MRI T2 강조영상은 특히 비인강이나 설근부에서 림프절의 종대 의 원인으로 점막하 종양이 있을 경우 확인하는데 종종 이용된다. 이 검사들은 조직검사를 시행받기전에 실시하 는 것이 영상진단에 혼란을 주지 않는다. ${ }^{4}$

그러나 이 검사만 단독으로 시행 후 치료 방침을 결정 하는 것은 대단히 위험하다. 반드시 이 검사들과 더불어 조직검사와 임상적인 소견에 근거를 두고 치료 방침을 결정해야 한다. ${ }^{4)}$

CT와 MRI의 영상은 병의 침범범위와 수술을 결정
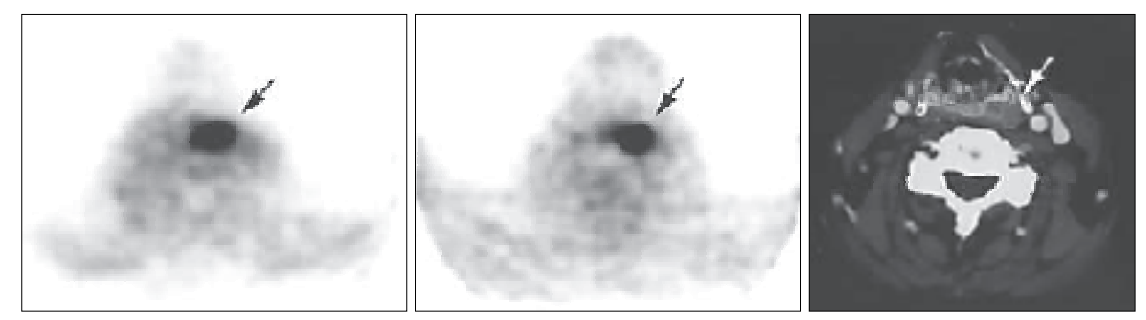

Fig. 2. FDG-PET imaging of hypopharyngeal carcinoma. 
하는데 유용하다. ${ }^{8)}$

$\mathrm{CT}, \mathrm{MRI}$ 에서 림프절 전이를 의심할 수 있는 소견은 아래와 같다

1) Level I 과 II에서 $1.5 \mathrm{~cm}$ 이상,

2) Level III, IV, V에서 $1.0 \mathrm{~cm}$ 이상,

3) 인두후림프절 (retropharyngeal lymph node)의 경우 $8 \mathrm{~mm}$ 이상인 경우로서 타원형보다 원형에 가까운 경우,

4) CT에서 림프절의 괴사가 의심되는 저음영,

5) 직경 8 15 mm의 경계가 불명확한 림프절이 세 개 이상 붙어 있는 경우,

6) MRI의 T1WI에서 저음영, T2WI에서 고음영을 나타내는 경우등이다. ${ }^{9)}$

\section{조직검사}

여러 가지 이학적 검사 및 영상 검사 후 염증성 림프 선병증이 의심되는 환자에게는 시험적으로 2 주간의 항 생제 치료를 시험적으로 시행해 보는 것이 좋다. 만약 2 주간의 항생제 치료로도 효과가 없고 크기가 더 커지는 경우엔 조직검사와 같은 다른 검사를 더 시행해 보아야 한다. ${ }^{4)}$

먼저 세침흡입검사를 시행 후 결과가 확실하지 않을 경 우 생검을 시행하여야 한다. 생검은 일반적으로 아래와 같 은 경우에 시행한다.

1) 점점 크기가 증가할 경우, 2) 단일의 비 대칭적 경 부 림프절 종대가 있을 경우, 3) 감염의 증상이 없으면 서 지속적인 림프절 종괴가 있을 경우, 4) 일반적인 항생 제에 반응이 없이 지속적인 활동적인 감염의 경우이다.

\section{세침흡인검사(Fine-needle aspiration)}

경부 종괴가 있는 경우 여러 가지 검사후 시행하게 되 는데 25-게이지 주사기가 추천된다(Fig. 3). 세침검사 에서 얻은 미세한 세포의 양으로 림프종의 진단을 위해 유세포분석(flow cytometry)이 사용되어 왔고 비인강 암의 진단을 위한 Epstein-barr virus를 확인하기 위 해 중합효소연쇄반응(polymerase chain reaction, PCR) 이 사용되어 왔다. ${ }^{10)}$

작은 구경의 주사바늘을 사용함으로 종양의 오염(tumor contamination)이나 확산의 위험이 적고, 침습도

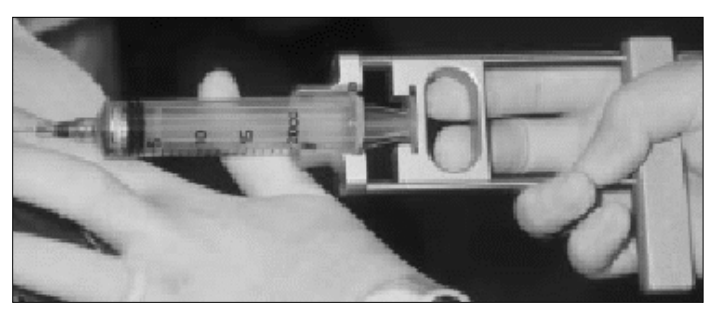

Fig. 3. Fine needle aspiration cytology.

가 낮고, 환자의 부담이 적은 장점이 있으며, 최근 들어 초음파 유도법(ultrasono-guided method)을 이용하 여 정확도가 더욱 향상되었다.

세침흡인세포검사는 염증성 질환에서 낭성종괴를 감 별할 수 있다. 그리고 겁이 많은 환자에게 종괴가 악성 이 아니라는 결과를 확인시켜줄 수 있는 장점이 있다.

종괴의 위치가 불분명하거나 절제생검을 할 수 없는 상황에서는 18 게이지의 초음파 유도침생검 (ultrasono - guided needle biopsy)을 시행하기도 한다. 이때에는 세침흡인세포검사보다는 다소 악성 종양 세포가 오염될 위험성이 있다. ${ }^{1)}$

내시경(Endoscopy) 검사 및 유도 생검법(Guided biopsy) 경부 종괴가 악성이며 원발병소를 찾을 수 없을 경우 에는 내시경 검사를 시행한다. 병변의 위치에 따라 가능 성이 있는 원발병소 위치를 염두에 두고 세밀하게 조사 하고 의심스러운 부위를 생검하게 된다. 그러나 육안적 으로 분명한 병변이 없는 경우에는 빈도별로 가장 가능 성이 높은 부위에 유도생검을 시행한다. 보통 비인강부 위, Rosenmuller's fossa, 구개편도, 설근부, 그리고 이 상와 등에 유도생검을 시행한다. ${ }^{11)}$ 이러한 방법으로 원 발병소 불명의 전이암의 경우 $20 \%$ 가량에서 원인을 새 로이 규명할 수 있다. ${ }^{11)}$

\section{생 검}

상기의 여러 검사로도 진단이 어려운 경우 생검을 시 행 할 수 있는데, 주로 절제생검(excision biopsy)을 시행해야 하며 절개생검(incision biopsy)은 불가피한 경우가 아니라면 시행하지 않아야 한다. 생검을 시행하 는 경우에도 곧바로 광범위 두경부 청소술(radical neck surgery)로 전환될 가능성이 있음을 명심하여 절개선 
을 설계하고 최대한 종양의 오염 및 확산을 방지하도록 하여야 한다. 경부 청소술시에는 조직생검 절개창을 포 함해서 제거해야 한다. ${ }^{12)}$

소아에서는 염증성질환이나 비특이적인 림프절의 반 응성 비대 등이 많다. 하지만 소아에서 절개생검을 가급 적 조기에 시행하여야 하는 경우는 림프절 종창이 쇄골 상부에 있는 경우, 림프절 종창이 있으면서 1 주일 이상 $38.3^{\circ} \mathrm{C}$ 이상의 고열이 지속되는 경우, 지속적인 체중감 소, 림프절 종창이 있으면서 주위 피부에 유착된 경우, 신생아 때 발견된 경부종괴, 지속적 혹은 빠르게 커지는 경우, 피부에 궤양을 형성한 경우, $3 \mathrm{~cm}$ 이상의 견고한 림프절, 고정된 림프절이 있는 경우 등이다. ${ }^{13)}$ 그 외에 2주 이상 치료해도 계속해서 림프절이 커진다든지, 4 6 주 치료 후에도 림프절 크기가 감소하지 않는 경우, 8 12주 치료 후에도 정상 림프절 크기로 돌아오지 않 는 경우에도 생검을 고려한다. ${ }^{13)}$

\section{림프절 비대의 위치에 따른 조직검사 부위 결정}

림프절 비대의 위치가 경부의 상부이거나 후 삼각부 위일 경우엔 비인강 부위를, 경정맥이복근 부위의 림프 절 비대가 있을 경우엔 편도, 설저부위, 성문상부 부위 를, 쇄골상부나 경부 하부에 림프절 비대가 있을 경우엔 소화관과 기관기관지, 유방, 갑상선 부위를 추가적으로
조직검사 해야할 필요가 있다(Fig. 4). ${ }^{4}$

\section{경부종괴의 특징}

\section{두경부 기원의 종물(Primary tumors in neck)}

\section{갑상선 종양(Thyroid neoplasm)}

전경부의 종물 중 가장 빈도가 높으며, 소아에서는 남 성에서 호발하고 악성일 가능성이 높지만, 성인에서는 양성의 빈도가 높고 여성에서 3 배 이상 호발한다. 림프 절 전이가 유두상암종에서는 약 $15 \%$ 에서 첫 증상으로 나타나고 악성종양의 $40 \%$ 에서 림프절전이 양성소견을 보인다. ${ }^{14)}$

그리고 수술시 제거된 림프절의 약 $90 \%$ 에서 조직학 적으로 양성 전이 소견 보인다. ${ }^{15)}$ 갑상선에 생기는 종 물은 악성일 가능성을 염두에 두고 진단을 진행해야 하 며, 일반적으로 초음파, 갑상선스캔, 갑상선기능검사, 초 음파유도 세침흡입검사가 필요하다. 초음파검사상 낭성 종괴로 나타날 경우에는 반드시 흡인하여 검사하여야 한 다. 전산화 단층촬영이나 자기공명영상은 주변 조직으로 의 침범이나 림프절 전이를 파악하는 데 유용하다(Fig. 5). 고형 종괴일 경우 기능성 여부는 핵의학검사인 갑상선 스캔을 이용하여 알아볼 수 있고 그 결과에 따라 치료방

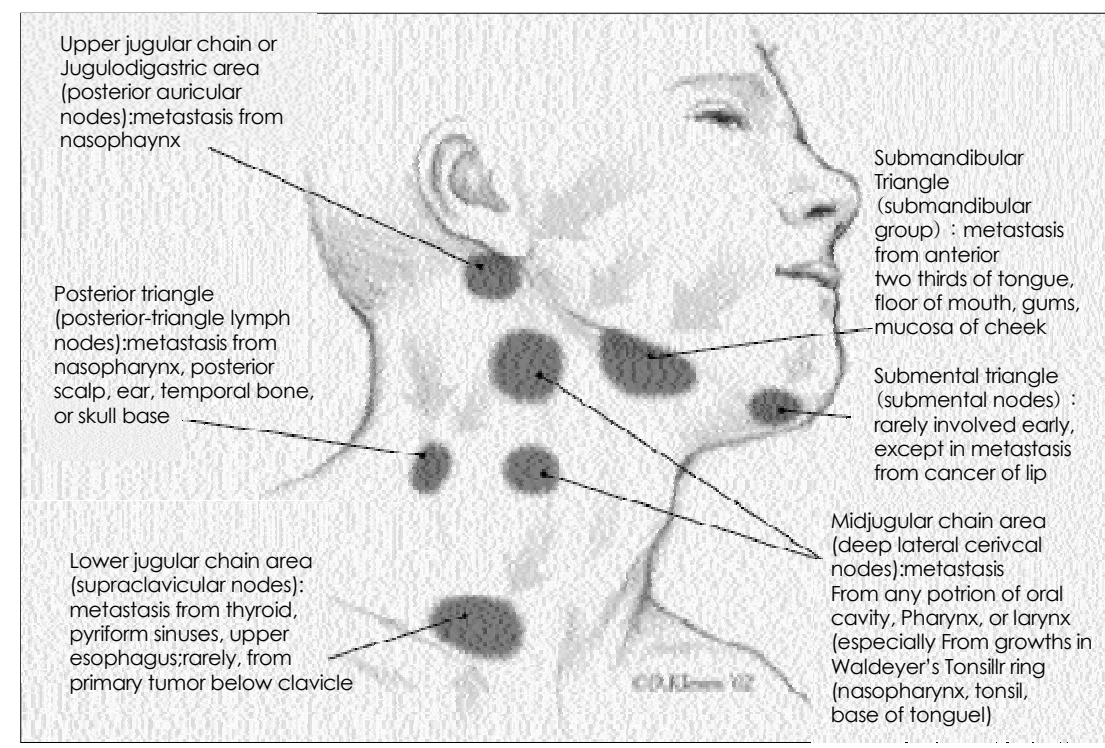

Fig. 4. Lymph node groups with most likely sites of the primary lesion. 


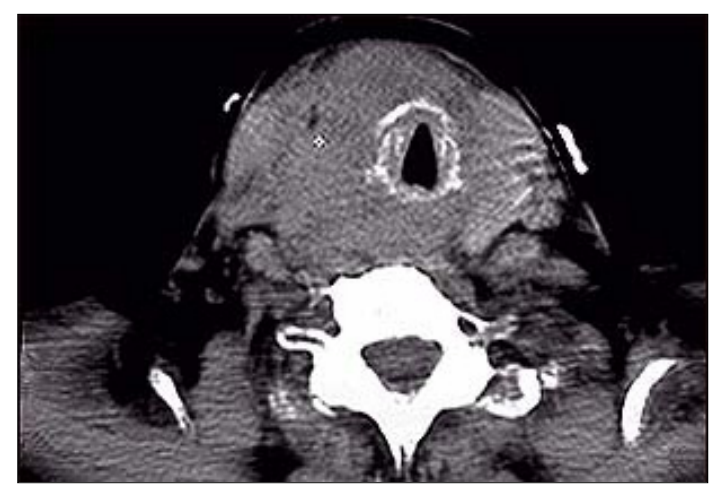

Fig. 5. CT imaging of thyroid cancer.

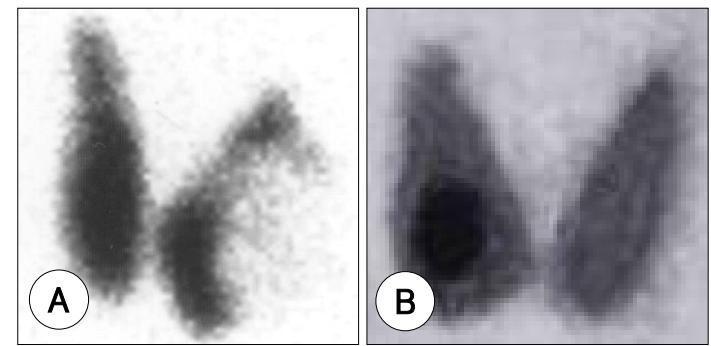

Fig. 6. Thyroid sacn. A : cold nodule, B : hot nodule.

침을 결정하여야 한다. 스캔상 냉결절(cold nodule)의 20 25\%가 낭성종괴로 나타났고 열결절(hot nodule) 의 경우 20 25\% 가 악성종양으로 나타났다(Fig. 6). ${ }^{16)}$

분화 갑상선암종에서 갑상선 절제 범위는 논란의 여 지가 있어서 위험인자를 고려하여 고위험군이 아니라면 전절제보다 작은 범위의 수술(less than total thyroidectomy)을 시행하자는 의견과 모든 예에서 전절제술(total thyroidectomy)을 시행하자는 상반된 의견이 존재 한다. ${ }^{17)}$

유두상 갑상선암종은 초기부터 중앙구획 림프절(central compartment lymph nodes) 전이가 일어나므로 수술시 중앙구획 림프절 청소술을 시행하자는 데는 이 견이 없다. 그러나 측경부 림프절에 대해 예방적 림프절 청소술(prophylactic lymph dissection) 에는 반대하는 의견이 지배적이며, 일본의 일부 학자들을 제외하고는 임상적으로 림프절 전이가 확인된 경우가 아니면 측경 부 림프절 청소술(lateral neck dissection)을 시행하지 않는다. ${ }^{12)}$

갑상선을 전절제하는 경우에는 수술 후 방사성 요오 드치료(radio-iodine ablation therapy)를 시행한다. 여 포상암에서는 혈행성 전이가 흔하고 좀 더 공격적인 양 상을 띠므로 갑상선 전절제와 방사성 요오드 치료를 동 시에 시행한다. ${ }^{12)}$

\section{악성 림프종(Malignant lymphomas)}

호지킨병(Hodgkin's disease) 과 림프육종등은 모든 연령대에 발생할 수 있지만 주로 소아 연령이나 청년기 에 호발하며, 소아 연령에서 발생하는 악성 종양의 약 $55 \%$ 를 차지한다. ${ }^{18)}$ 주로 전신적인 질환이지만 호지킨 병(Hodgkin's disease)의 70\%, 비호지킨 림프종(non -Hodgkin's lymphoma) 의 30\%가량에서 두경부의 증 상으로 나타나고 세침흡입검사와 유세포분석(flow cytometry), 그리고 세침흡인검사에서 림프종이 의심된다 고 나왔을 경우 절제 생검을 통해 진단된다. ${ }^{19)}$ 일반적 으로 경부의 증상은 분리된 고무양상의 무압통 종괴로 나타난다. 소화기관 및 중추신경계와 연관될 수 있기 때 문에 전신적인 전이에 대한 정밀한 검사가 필요하고, 질 환이 두경부에 국한된 경우에는 방사선조사 등 국소적 인 치료만으로 가능하지만 그렇지 않은 경우에는 전신 적인 화학요법이 필요하다. ${ }^{20)}$

\section{타액선 종양(Salivary gland tumors)}

일반적으로 이개전 부위, 이개하 부위, 하악각부위, 그 리고 하악삼각부위에 고형의 종괴가 있을 경우 의심한 다. 무통성 종물이 이하선, 악하선 부위에 만져져서 진 단되며, 타석(salivary stone)으로 인한 타액선염증(sialadenitis)으로 증상이 있는 경우도 있지만 양성종양일 경우 증상이 없는 것이 대부분이다. 하지만 통증, 자라 는 속도가 빠를 경우, 안면신경마비가 있을 경우, 피부 에 고장되어 있을 경우 악성종양을 의심할 수 있다. 초 음파검사보다는 전산화 단층촬영, 자기공명영상 등이 진 단적 가치가 있으며, 와틴씨종양(Warthin's tumor)은 핵의학 검사가 도움이 된다. 세침흡입검사를 통해 진단 을 할 수 있고 수술의 최소단위는 악하선(submandiular gland)에서는 전절제, 이하선(parotid gland)에서 는 천엽 절제(superficial parotidectomy)이다. ${ }^{12)}$

특히 이하선 종양의 경우에는 안면신경 분지의 손상 을 방지하며 조심스럽게 수술을 시행하여야 한다. 다형 
성선종(pleomorphic adenoma)의 경우 충분한 변연을 확보하지 못하였다면 재발의 가능성이 높으므로 주의를 요한다.

\section{경동맥체 종양(Carotid body tumor)}

경동맥 분지부위의 전삼각부에 박동성이고 압박한 후 압박을 풀었을 경우 다시 재충만되는 양상의 종괴로 나 타난다. 좌우로 움직이나 상하로 움직이지 않는 특징이 있다. 소아 연령군에서는 드물지만 고연령층에서 빈도가 증가하고, 대부분 일측성이지만 가족력이 없는 경우 $5 \%$ 에서, 가족력이 있는 경우의 $30 \%$ 에서 양측성으로 나타

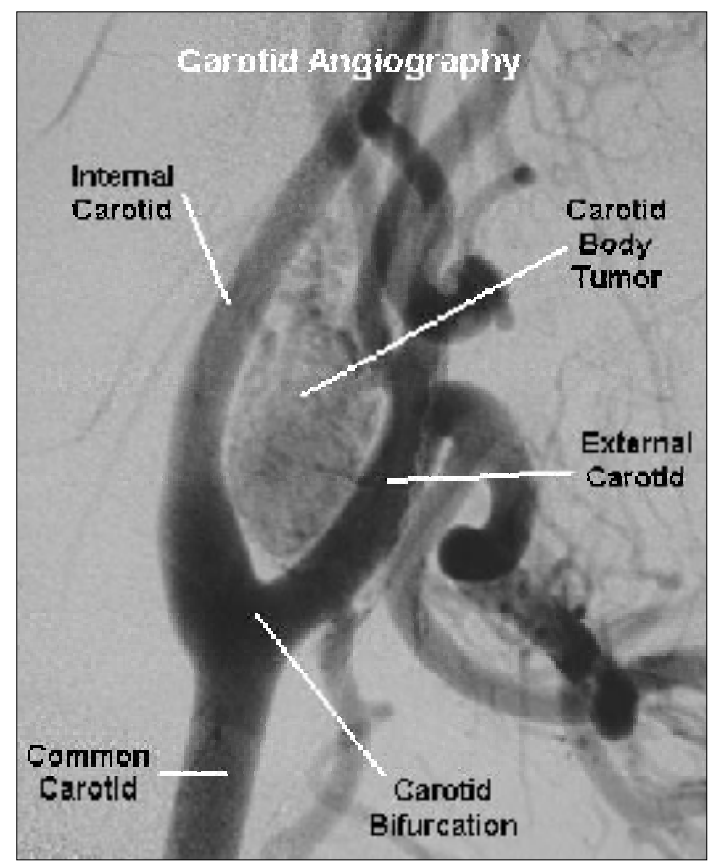

Fig. 7. Angiogram of carotid body fumor (lyre sign).
난다. $^{21)}$

전산화 단층촬영, 자기공명영상이나 동맥혈관조영술 로 진단할 수 있다(Fig. 7). ${ }^{22)}$ 기능성 종양이 의심될 때 에는 전신적인 검사가 필요하며 $\mathrm{MIBG}$ 스캔을 시행하 고, 혈장 카테콜아민과 요 중 metanephrine, normetanephrine, VMA(vanillylmandelic acid) 등의 상승여부 를 확인한다. ${ }^{23)}$

감별하여야 할 종괴로는 새열낭, 경동맥 동맥류, 전이 성 암, 미주신경내 종양, 림프종, 이소성 갑상선 등이 다. $^{24)}$

고연령층에서는 관찰만 하거나 방사선치료를 하는 경우가 있지만 크기가 작고 젊은 연령군에서는 외막하 절제(subadventitial resection) 가 바람직하다. ${ }^{25)}$

큰 종괴에서는 동맥 혈관조영술을 통한 색전술이 출 혈을 줄이므로 종괴를 제거하는데 도움을 준다. ${ }^{26)}$

비록 부신경절종은 방사선 치료에 저항적이지만 종괴 가 크거나 수술이 어려울 경우에는 방사선 치료를 시도 하기도 한다. ${ }^{27)}$

\section{신경초종이나 신경종}

신경초종이나 신경종은 부인두강에서 가장 많이 발생 한다(Fig. 8). 이학적 검사상 구개편도를 내측으로 미는 양상을 보인다. 미주신경 기원의 종양은 애성을 야기하 고, 교감신경기원의 종양은 호너증후군(Horner's syndrome) 을 야기하기도 한다. 증상이 없는 경우에는 관 찰만 하는 것이 원칙이나 수술을 고려하는 경우 최대한 운동, 감각 기능을 보존하는 것이 최우선시 되어야 한다.

\section{지방종}

지방종(lipoma)은 주로 35세 이상의 연령층에서 호
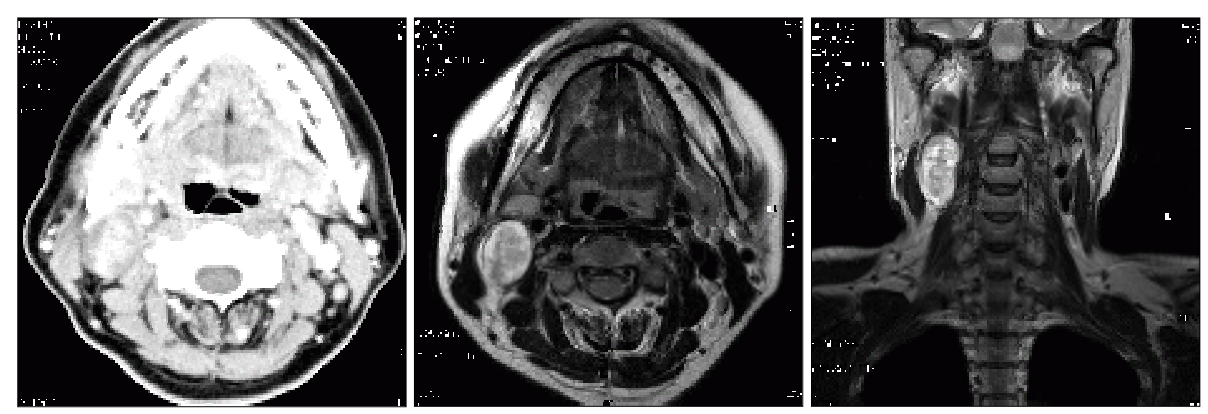

Fig. 8. CT and MRI finding of neurogenic tumor occupying parapharyngeal space. 
발하며 일반적으로 증상이 없으며 특별한 문제가 없는 경우에는 역시 관찰만 하는 것이 원칙이다. ${ }^{12)} \mathrm{CT}$ 상 지 방종은 지방-공기 강도로 보인다.

\section{전이성 두경부 종물(Metastatic tumors in neck)}

두경부에서 갑상선 종물을 제외한 종물의 $80 \%$ 가량 이 악성 종양으로 알려져 있고, 특히 50대 이상에서는 $90 \%$ 가량이 악성이다. 이들 중 60 70\%는 상기도, 상 부 소화관을 포함한 두경부에서 기원하고, 10 20\%가 쇄골하부의 기원인 것으로 알려져 있다. 그리고 나머지 $5 \sim 10 \%$ 가 근원 불명의 전이성 두경부암인 것으로 알려 져 있다. ${ }^{28)}$

원인 불명의 전이성암에서 $\mathrm{N} 1$ 군에 대해서는 부분 림 프절 청소술(regional node dissection)을 시행하는 것 이 권장되고, N2, N3군의 경우 완벽한 경부 청소술(radical neck dissection)을 시행하는 것이 바람직하다. 경 부 청소술 후 예방적 방사선치료에 대해서는 논란의 여 지가 많지만, $\mathrm{N} 2, \mathrm{~N} 3$ 군에서는 시행하는 것이 바람직하 다는 의견이 많다. 일반적으로 원인 불명 두경부 전이암 의 5 년 생존율은 $50 \%$ 가량이지만 쇄골 상부의 전이성 림프절로 나타난 경우에는 $10 \%$ 가량으로 감소하는 것 으로 알려져 있다.

\section{염증성 종물(Inflammatory masses)}

단순 림프절 비대(Reactive lymphadenitis)

거의 전 연령층에서 나타나며 10 대 이전에 특히 많이 발생한다. ${ }^{29}$

주로 상기도 및 상부 소화관에서 기원한 세균이 원인 이 되며, 양측성이고 전·후경부에 다 나타날 수 있다. 특별한 배양검사 및 감수성 검사로 적절한 항생제를 선 택하여야 한다. 혐기성(anaerobic), 그람양성균(grampositive organism)에 대한 항생제 치료가 일차적인 치 료이며, 약 1 2주 가량의 약물 사용으로 크기의 감소가 있는 경우 진단적인 가치도 있다.

림프절 비대가 편측성이고 점점 자라는 경우, 쇄골상 방(supraclavicular area)에 위치하거나 병력과 과거력 에서 의심스러운 소견이 있는 경우엔 확진을 위해서절 제 생검을 하는 것이 좋다. ${ }^{13)}$
농 양(Abscess)

신생아기에 자주 볼 수 있으며, 주로 이복근하(subdigastric area), 하악하(submaxillary area)에 나타나며, 세균성 림프절염(bacterial lymphadenitis)이 악화되어 일어난다. 필요할 경우 배농술이 선택될 수 있지만 항생 제로도 충분히 치료될 수 있다. ${ }^{13)}$

\section{육아종성 림프절염(Granulomatous lymphadenitis)}

주로 정형, 비정형 미코박테리아(typical, atypical Mycobacteria)의 감염으로 인하며, 우리나라에서 30대 이 하의 청소년층에서는 결핵을 제일 먼저 생각하여야 한 다. 대부분 흥쇄유돌근 후방 경계부위의 후경삼각에서 나타나며, 편측성, 양측성으로 나타날 수 있고, 급격하게 진행되는 경우에는 냉농양(cold abscess)을 형성하기 도 한다. 또한 농양이 터져서 장기간 잘 낫지 않는 누공 (fistula)을 형성할 수도 있다. 세침흡입검사로도 진단율 이 높으며, 절개창이 잘 낮지 않을 가능성이 높으므로 절 개 생검은 최대한 피하는 것이 좋다. ${ }^{5)}$

결핵이 확진된 다음에는 장기간의 항결핵제 치료를 하 고, 감염림프절의 소실을 확인한 후 약물치료를 종료하 게 된다. ${ }^{12)}$

흔하지는 않지만 방선균 감염(actinomycosis), 사르 코이드증 (sarcoidosis), 묘소열(cat-scratch disease) 등이 있을 수 있다. ${ }^{4}$

\section{후천면역결핍증후군(Acquired immunodeficiency sy- ndrome, AIDS)}

경부 림프절 증식증은 인체면역결핍 바이러스에 감염된 환자에게 흔하게 나타나고 조직검사를 필요로 한다. 조 직검사를 시행해야 하는 경우는 단일의 급속히 자라는 종 괴, 새로이 나타난 압통의 종괴, 전신적인 면역체계의 변 화와 함께 나타난 종괴, 단일의 $3 \mathrm{~cm}$ 이상 크기의 림프 체계를 따라 나타난 종괴가 있을 경우 등이다. ${ }^{6)}$ 보통 조 직검사가 필요하다면 세침흡인검사를 시행하는 것이 좋다.

\section{손상성 종괴(Traumatic masses)}

외상의 후유증으로 경부종괴의 양상으로 나타나게 된 다. 보통 출산시 겸자에 의한 외상으로 흥쇄유돌근내의 전경부 부위에 종괴의 양상으로 나타나는 경우가 많다. 
이러한 혈종은 인대모양종양이나 육종과 혼돈되는 수도 있다. 열찜질이나 마사지, 혹은 경과관찰 만으로도 종종 치유되는 경우가 있다.

지속적으로 커지는 경우나 증가하는 사경(torticollis) 등은 수술을 고려하여야 한다. ${ }^{30)}$

그 외 외상 후 생길 수 있는 종괴로는 혈관의 가성 동 맥류(pseudoaneurysm), 신경의 손상으로 인한 신경종 (neuroma), 혈종 후 섬유종(hematoma with subsequent fibroma) 등이 있다. ${ }^{42)}$

\section{선천성 종물(Congenital masses)}

대부분 신생아기나 소아기에서 발견되며 발생단계의 이상에서 기인한다.

새열낭 혹은 누공(Branchial cleft cysts or fistulae)

대부분 소아기 후반(late childhood)이나 청년기(early adulthood)에 호발하고 감기 등 상기도 감염 후 나 타나게 된다. 종종 통증, 종창, 압통, 열을 동반하는 염 증성 종괴의 양상으로 나타나기도 한다.

적절한 항생제 치료로 낭은 줄어들 수 있지만 종종 지속적으로 경부의 전삼각부에 연하고 말랑말랑하고 다 양한 크기의 종괴로 남아있다.

주로 낭으로 나타나지만 터져서 누공의 형태를 보이 는 경우도 있다. 가장 흔한 형태는 제2형(2nd type)으 로 흉쇄유돌근 전연에서 상부로 진행하여 경동맥 분지 사 이를 통해 구강인두부(oropharynx)로 들어간다(Fig. 9). 초음파 검사에서 낭종형 종괴를 확인하는데 도움을 주

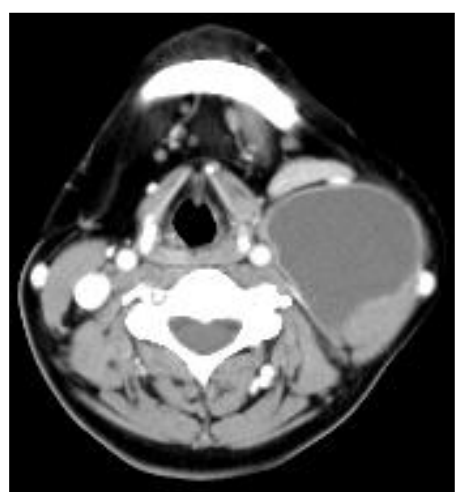

Fig. 9. CT imaginn of 2nd branchial cleft cyst.
며 흡인검사에서 특징적인 소견을 보인다.

우유같거나, 점액성이거나, 갈색의 양상을 띄며 종종 콜레스테롤 결정들을 포함한다. 수술시 낭종의 가장 상 위부까지 올라가 구강인두부로 들어가는 부위에서 결찰 해 주어야 재발을 방지할 수 있다. ${ }^{31)}$

피지낭, 표피낭(Sebaceous and epidermal cysts)

가장 흔한 선천성 종물로서 비교적 고연령층에서 흔 히 나타난다. 피부에 특징적인 함몰부위나 구멍 (dimple or pore)을 가지고 있으며, 피막을 포함한 완벽한 절제 로 재발을 방지할 수 있다. ${ }^{4)}$

\section{갑상설골낭(Thyroglossal duct cysts)}

태생기 갑상선이 하강한 후 퇴화되어야 할 갑상설관 이 출생 후에도 계속 잔존하여 낭을 형성한 것으로 성 별의 차는 없으며, 15 세 이하 소아의 경부 중앙부 종괴 의 가장 많은 원인이다. ${ }^{32)}$ 주로 전경부의 정중부에 나 타나며 새열낭종과 마찬가지로 상기도 감염 후 잘 나타 난다(Fig. 10). 감염이 해소된 후 초음파 검사를 통해 유피낭(dermoid cyst), 이소성 갑상선(ectopic thyroid), 림프선염과 감별이 가능하며, 삼키거나 혀를 내밀 때 상 하로 움직이는 특징을 보인다. 낭종의 경로를 모두 포함 하는 완벽한 절제로 재발을 방지할 수 있으며, 설골(hyoid bone) 중앙부위를 절제하는 시스트렁크 수술(Sistrunk's operation)을 시행한다. 흔하지는 않지만 갑상 선 조직이 포함되어 있는 경우도 있고, 이 조직에 갑상 선암이 발생한 경우도 있다. ${ }^{33)}$

\section{이소성 갑상선}

갑상선의 발생단계에서 혀의 기저부위 맹공(foramen
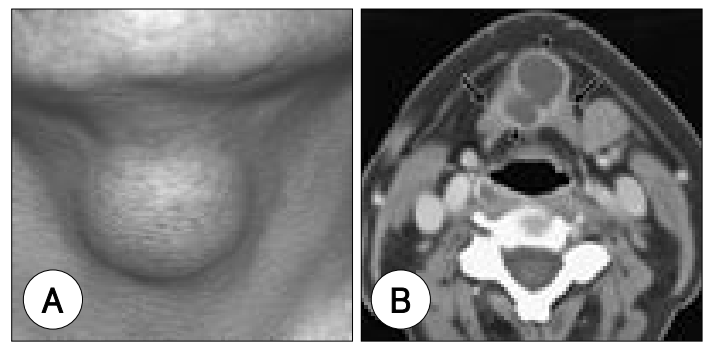

Fig. 10. Local finding (A) and CT imaging (B) of thyroglossal duct cyst. 
cecum)에서 발생한 갑상선 선구조직이 정상 갑상선 위 치로 하강하던 도중에 정체된 것을 말하며, 하강 도중 어느 부위에도 생길 수 있다. 초음파검사나 갑상선 스캔 (thyroid scanning)으로 손쉽게 진단이 된다. 종물로 인한 증상이나 미용적인 문제, 조직 내 종양의 발생 등 의 문제가 없다면 꼭 수술을 필요로 하지는 않는다. 만 약 수술을 고려할 경우에는 이소성 갑상선 외에 갑상선 조직이 있는지 조사한 후 시행하여야 하며, 그렇지 않은 경우에는 갑상선 기능저하증을 초래할 수 있으므로 주 의를 요한다. ${ }^{34)}$

\section{림프관종(Lymphangioma)}

선천적으로 두경부 림프관의 일부가 폐쇄되어 발생하 는 것으로 알려져 있고, 주로 신생아기와 영아기에 나타 나며, 두경부의 어디에서나 있을 수 있지만 후경부에 호 발한다. 경부 림프관종은 파동성, 연성, 스펀지 양상의 경계가 불분명한 종괴로 나타난다. 부드러운 수술적인 절제는 손쉽게 절제될 수 있는 경우 등 제한적인 경우 에만 권장되며, 재발의 가능성이 높은 광범위한 병변의 경우엔 picibanil(OK-432) 등으로 경화요법(sclerosing therapy) 과 같은 보존적인 방법을 사용하기도 한다. ${ }^{35)}$

\section{혈관종(Hemangioma)}

림프관종과 마찬가지로 선천적인 원인으로 생각되고, 출생시 혹은 1 세 이전의 신생아기에 나타난다. 두경부 보다는 안면에 호발하고 피부의 색깔 변화, 잡음, 진동, 압박 후 재충만(compressible and refilling) 등의 특징 이 나타나며, 동맥조영술이 진단적 가치가 있지만 잘 사 용되지 않는다.

급속한 성장을 보이거나, 혈소판 감소 등의 증상이 있 거나, 중요 활력 장기를 침범하는 경우가 아니라면 수술 을 고려하지 않는다. 대부분의 경우 저절로 없어진다. 새 로운 pulse-dye 레이저가 혈관종의 빠른 치유에 많은 도움을 주고 있다. ${ }^{36)}$

\section{유피낭종(Dermoid csts)}

새열낭종 혹은 갑상설낭종 처럼 주로 전경부의 정중 선에 호발하며 표피낭종과 유사한 양상을 보이나 이와 는 달리 경부근막(cervical fascia)보다 심부에 발생하
고 천층의 피부가 자유롭게 움직인다. ${ }^{35)}$ 단순절제로 쉽 게 치유된다. 초음파검사상 낭 내부에 분비물의 흔적 (sludge)이 보이기도 한다.

기 타

후두낭(laryngocele), 인두게실(Zenker's or pharyngeal diverticuli), 이소성 흉선(thyrmic arrest), 흉선 낭(thymic cyst) 등이 있다.

중심 단어 : 경부종괴 · 진단

\section{REFERENCES}

1) Cummings CW, Larson SM, Dobie RA, Weymuller EA, Rudd TG, Merello A. Assessment of cobalt 57 tagged bleomycin as a clinical aid in staging of head neck carcinoma. Laryngoscope 1981;91:529-37.

2) Bhattacharyya N. Predictive factors for neoplasia. Arch Oto 1999;125:303-7.

3) DeVita VT Jr, Jaffe ES, Hellman S. Hodgkin's disease and the non -Hodgkin's lymphomas. In: DeVita VT Jr, Hellman S, Rosenberg SA, eds. Cancer. Principles and Practice of Oncology. 2nd ed. Philadelphia: JB Lippincott Co; 1985. p. $1623-710$.

4) McGuirt WF. Differential diagnosis of neck masses. In: Cummings CW, Fredrickson JM, Harker LA, Krause CJ, Schuller DE, editors. Otolaryngology-Head and Neck Surgery, 4th ed. St. Louis: Mosby Year Book; 2002. p.2540-53.

5) Altman RP, Margileth AM. Cervical lymphadenopathy from atypical mycobacteria: Diagnosis and surgical treatment. $J$ Pediatr Surg 1975;10:41-7.

6) Burton F, Patete ML, Goodwin WJ. Indications for open cervical node biopsy in HIV-positive patients. Otolatyngol Head Neck Surg 1992;107:367.

7) Greven K, McGuirt WF. The emerging role of positron emission tomography in the management of head and neck cancer. Curr Opin Otol-HNS 1999;7:48-51.

8) Underhill T, McGuirt WF, Williams DW. Advances in imaging in head and neck tumors. Current Opinions in OtolHNS 2000;8:91-7.

9) Som PM. Detection of metastasis in cervical lymph nodes: $C T$ and MR criteria and differential diagnosis. Am J Radiol 1992;158:961-9.

10) Feimmesser R and others. Diagnosis of nasopharyngeal carcinoma by DNA amplification of tissue obtained by fineneedle aspiration. N Engl J Med 1992;326:17.

11) McGuirt WF. Panendoscopy as a screening examination for simultaneous primary tumors in head and neck cancer: A prospective sequential study and review of the literature. Laryngoscope 1982;92:569-76.

12) MacComb WS. Diagnosis and treatment of metastatic cervical cancerous nodes from unknown primary site. Am J Surg 1972;124:441-9.

13) Knight PJ, Mulne AF, Vassy LE. When is lymph node bio- 
psy indicated in children with enlarged peripheral nodes? Pediatrics 1982;69:391-6.

14) Maddox PR, Malcolm HW. Approach to thyroid nodules. In: Clark OH, Duh QY, Kebebew E, eds. Textbook of Endocrine Surgery. 2nd ed. Philadelphia: Elsevier Saunders, 2005. p. 85-92.

15) McGuirt WF. Management of occult metastatic cervical disease from well-differentiated thyroid carcinoma. Ear Nose Throat J 1989;68:170.

16) Gooder K, Palmer M. Cervical lymph node biopsy: a study of its morbidity. J Laryngol Otol 1984;98:1031.

17) Clark OH. Papillary thyroid carcinoma: Rationale for total thyroidectomy. In: Clark OH, Duh QY, Kebebew E, eds. Textbook of Endocrine Surgery. 2nd ed. Philadelphia: Elsevier Saunders;2005. p.110-3.

lymphomas: diagnosis, staging, and therapy. In Shockley WW, Pillsbury

18) Giles FJ, Timmis HH jr. Hodgkin's disease and the nonHodgin's HC III, editors: The neck: diagnosis and surgery, St Louis, 1994, Mosby.

19) Cannon CR, Richardson LD. Value of flow cytometry in the evaluation of head and neck fine needle lymphoid aspirations. Otolaryngol Head and Neck Surg 1992;107:367.

20) Shapiro AL, Pincus RC. Fine needle aspiration of diffuse cervical lymphadenopathy in patients with acquired immunodeficiency syndrome. Otolaryngol Head Neck Surg 1991; 105:419-21.

21) Wang SJ, Wang MB, Barauskas TM, Calcaterra TC. Surgical management of carotid body tumors. Otolaryngol Head Neck Surg 2000; 123:202-6.

22) Muhm M, Polterauer P, Gstottner W, Temmel A, Richling B, Undt G, et al. Diagnostic and therapeutic approaches to carotid body tumors: Review of 24 patients. Arch Surg 1997; 132:297-84

23) Seo MC, Lee KS, Kim CJ, Kim SY. Multiple paragang- liomas: three cases. Korean J Otolaryngol 2000;43:442-6.

24) Meyer FB, Sundt Jr TM, Pearson BW. Carotid body tumors: a subject review and suggested surgical approach. $J$ Neurosurg 1986;64:377-85.

25) McGuirt WF, Harker LA. Carotid body tumors. Arch Otolaryngol 1975;88:594.

26) Murphy TP, Brackmann DE. Effect of preoperative embolization on glomus jugulare tumors. Laryngoscope 1989; 66:1244.

27) Valdagni R, Amichetti M. Radiation therapy of carotid body tumors. Am J Clin Oncol 1990;13:45-8.

28) Coker DD, Casterline PF, Chambers RG, Jaques DA. Metastases to lymph nodes of the head and neck from an unknown primary site. Am J Surg 1977;134:517-22.

29) Herzog LW. Prevalance of lymphadenopathy of head and neck in infants and children. Clin Pediatr 1983;22:485.

30) Tom LWC. Torticollis in children. Otolaryngol Head Neck 1991;105:1.

31) Drake AF, Hulka GF. Congenital Neck Masses. In: Shockley WW, llsbury HC III, eds. THE NECK Diagnosis and Surgery. St. Louis: Mosby -Year Book; 1994. p.93-107.

32) Athow AC, Fagg NL, Drake DP. Management of thyroglossal cysts in children. Br J Surg 1989;76 (8):811-4.

33) Sistrunk WE. Technique of removal of cysts and sinuses of the thyroglossal duct. Surg Gynecol Obstet 1928;46:109.

34) McGuit WF. Neck Masses: Differential Diagnosis and Therapeutic Approach. In: Shockley WW, Pillsbury HC III, eds. THE NECK Diagnosis and Surgery. St. Louis: Mosby -Year Book; 1994. p.73-89.

35) Greinwald JH jr. Treatment of lymphangioma in children: an update of picibanil (OK-432) sclerotherapy. International J Pediatric Otolaryngol 2002;65:1-6.

36) Morelli JG. Tunable dye laser $(577 \mathrm{~nm})$ treatment of port wine stains. Laser Surg Med 1986;6:94. 